\title{
THE DEVELOPMENT OF LOCAL CULTURE THROUGH TRADITIONAL GAMES FOR CHILDREN AT RUMAH PENDIDIKAN ASAH ASIH ASUH
}

\author{
Gamma Rahmita Ureka Hakim \\ State University of Malang
}

\begin{abstract}
Rumah Pendidikan Asah Asih Asuh is a community initiated by youth that feel our local culture has been eroded at younger generation, especially regarding tolerance and politeness. Therefore, this community is formed to develop local culture among children who will be the successor to the nation's culture. Considering the development of children that prefers learning through playing model, this community develop learning strategies with traditional games. Through this game, children are taught how to respect and loving others in politeness. In addition, children also learn about social communication, not only with friends of his age but also with younger or older. This study, as a preliminary study, are trying to describe Rumah Pendidikan Asah Asih Asuh to develop local culture among children that join with this community. This study uses qualitative approach by conducting interviews with three Rumah Pendidikan Asah Asih Asuh initiators for data collection. The results of this study indicate that the initiators feels the children develop positively after join this community. They see that this community helps them gain tolerance to others. The children also more polite and respect to their parents. Parents also conveyed when this community make some gathering for them. They said that their children now always taking care of their own stuff, always kissing hands when go out, tolerance to their sibling and more communicative. This result also recommends that playing traditional games are still needed and can not be replaced by high technology gadget-based games.
\end{abstract}

Keywords: development, local culture, traditional games

\section{INTRODUCTION}

Undang-Undang Republik Indonesia Nomor 20 tahun 2003 Pasal 3 UU Sisdiknas stated that "National Education serves to develop and form the character and civilization of the nation's dignity in the context of the intellectual life of the nation; aims to developing students' potentials in order to become a human that faith and fear of God Almighty, noble, healthy,knowledgeable, skilled, creative, independent, and become democratic and accountable citizens." Therefore it is the formal education that related should provide learning which aims to strengthen the nation's character. Schools are expected to enter cultural values in the learning so that these characters internalized by the students, in this case children.

It is also reinforced by Peraturan Menteri Pendidikan dan Kebudayaan Republik Indonesia Nomor 23 tahun 2015 that stated one of Penumbuhan Budi Pekerti purpose is to develop a good habit as a form of character education since in the family, school, and community. However, in real conditions in the field of formal education tend to lead to the fulfillment of academic factors alone. Meanwhile, the formation of character less affordable. Currently, children tend to learn to pursue high value so that the factors shaping the character less attention. This gave rise to a phenomenon in which the character of the nation 
began to fade among children. They tend to be individuals, are less sensitive to ambient conditions, lack of tolerance and less courteous towards others. While these things are characters that have become the nation's culture

One cause of this phenomenon is related to the modernization of poorly controlled use of technology. Bordova \& Leong (2003) emphasizes that 'Nowadays young children spend less time playing with their peers and more time playing alone, graduating from educational toys to video and computer games'. Children can use the gadget in the whole time of its activities so they tend to become apathetic and less sensitive to ambient conditions. Kurniati (2006) proposes that modern playing phenomena characterized by high technology model have given an immense influence on child development. Beside their positive effects, these plays can also provide negative effects to child development, such as creating an anti social individual because the plays are passive plays that minimize the child opportunity to interact and develop other social skills.

Parents also tend to use the gadget to soothe their children and little to interact directly with them. Parents also tend to be focused on questioning the child in terms of academic ability. Schools, as a place of education also started to get carried away because of the demands of the material to be taught so focused on the completion of teaching materials.

Rumah Pendidikan Asah Asih Asuh looks at the phenomenon which happens to be an important issue to be handled. Therefore, they formed a community which aims to develop the character of the nation that became the nation's culture avoid increasing their erode. The focus of its activities to teach children how to be polite and tolerant and train their social interactions. Rumah Pendidikan Asah Asih Asuh is a community initiated by youth that feel our local culture has been eroded at younger generation, especially regarding tolerance and politeness. Therefore, this community is formed to develop local culture among children who will be the successor to the nation's culture. Considering the development of children that prefers learning through playing model, this community develop learning strategies with traditional games. Through this game, children are taught how to respect and loving others in politeness.
In addition, children also learn about social communication, not only with friends of his age but also with younger or older. From playing games they hope children feel more comfortable with their program and more understand the goal of the program

\section{Principle of Child Development and Learning}

In 2009, National Association for the Education of Young Children (NAEYC) stated there were 12 principles of Child Development and Learning:

1. All the domains of development and learningphysical, social and emotional, and cognitiveare important, and they are closely interrelated. Children's development and learning in one domain influence and are influenced by what takes place in other domains.

2. Many aspects of children's learning and development follow well documented sequences, with later abilities, skills, and knowledge building on those already acquired.

3. Development and learning proceed at varying rates from child to child, as well as at uneven rates across different areas of a child's individual functioning.

4. Development and learning result from a dynamic and continuous interaction of biological maturation and experience.

5. Early experiences have profound effects, both cumulative and delayed, on a child's development and learning; and optimal periods exist for certain types of development and learning to occur.

6. Development proceeds toward greater complexity, self-regulation, and symbolic or representational capacities.

7. Children develop best when they have secure, consistent relationships with responsive adults and opportunities for positive relationships with peers.

8. Development and learning occur in and are influenced by multiple social and cultural contexts. 
9. Always mentally active in seeking to understand the world around them, children learn in a variety of ways; a wide range of teaching strategies and interactions are effective in supporting all these kinds of learning.

10. Play is an important vehicle for developing selfregulation as well as for promoting language, cognition, and social competence.

11. Development and learning advance when children are challenged to achieve at a level just beyond their current mastery, and also when they have many opportunities to practice newly acquired skills.

12. Children's experiences shape their motivation and approaches to learning, such as persistence, initiative, and flexibility; in turn, these dispositions and behaviors affect their learning and development

Based on the principles above, are arranged program that are considered effective enough to provide learning in children in a comprehensive manner. Developmentally appropriate practiceis grounded both in the research on child development and learning and in the knowledge base regarding educational effectiveness in early care and education. (NAEYC,2009).

\section{Developmentally Appropriate Practice}

NAEYC (2009) make a guidelines address decisions that early childhood professionals make in the five key (and interrelated) areas of practice: (1) creating a caring community of learners, (2) teaching to enhance development and learning, (3) planning curriculum to achieve important goals, (4) assessing children's development and learning, and (5) establishing reciprocal relationships with families.

1. Creating a caring community of learners. The foundation for the community is consistent, positive, caring relationships between the adults and children, among children, among teachers, and between teachers and families. It is the responsibility of all members of the learning community to consider and contribute to one another's well-being and learning.

2. Teaching to enhance development and learning. Developmentally appropriate teaching practices provide an optimal balance of adult-guided and child-guided experiences. "Adult-guided experience proceeds primarily along the lines of the teacher's goals, but is also shaped by the children's active engagement; child-guided experience proceeds primarily along the lines of children's interests and actions, with strategic teacher support."But whether a learning experience is adult- or child-guided, in developmentally appropriate practice it is the teacher who takes responsibility for stimulating, directing, and supporting children's development and learning by providing the experiences that each child needs.

3. Planning curriculum to achieve important goals. In developmentally appropriate practice, the curriculum helps young children achieve goals that are developmentally and educationally significant. The curriculum does this through learning experiences (including play, small group, large group, interest centers, and routines) that reflect what is known about young children in general and about these children in particular, as well as about the sequences in which children acquire specific concepts, skills, and abilities, building on prior experiences.

4. Assessing children's development and learning. Assessment of children's development and learning is essential for teachers and programs in order to plan, implement, and evaluate the effectiveness of the classroom experiences they provide.

5. Establishing reciprocal relationships with families. Practice is not developmentally appropriate if the program limits "parent involvement" to scheduled events (valuable though these may be), or if the program/family relationship has a strong "parent education" orientation. Parents do not feel like partners in the relationship when staff members see themselves as having all the knowledge and insight about children and view parents as lacking such knowledge.

Florida department of Children And Families (2013) also introduce to understanding Developmentally Appropriate Practice(DAP) that focuses on children birth to eight years old and is made up of three principle components: age appropriateness, individual appropriateness and cultural appropriateness. 
1. Age appropriateness means considering what is typical for a child within a given age group. Knowing the typical behaviors and growth patterns for certain age group is necessary to plan the most appropriate environments and activities to optimize the learning experience for children in your care.

2. Individual appropriateness means considering the needs of each child as a unique individual. A child's age temperament, personality and family history are all factors that affect their development.

3. Cultural appropriateness means considering the social and cultural contexts in which children grow and live. Caregivers should be intentional about planning learning experiences that are purposeful, challenging and achievable.

\section{Traditional Games to Develop Local Culture}

Kurniati (2006) stated that traditional plays are considered as high touch plays - plays with full social touch - that enable children to interact and to improve social experience to one another. Syaodih, et.al. (2006) also support that These traditional plays are proven to be very helpful in developing child's potential, such as gross motor, fine motor, social, cognitive, and other developmental aspects. In addition, interaction among children during the plays may enable them to develop their social, language, and emotional skill.

Catron \&Allen (Musfiroh,2005;Kurniati, 2016) argued that plays supported social development like:

1. Social interaction, ie interaction with peers, adults, and solve a conflict

2. Cooperation, ie the interaction of helping each other, sharing, and taking turns

3. Conserve resources, use and maintain the objects and the environment appropriately

4. Caring for others, such as understanding and accepting individual differences, understand multicultural issues

According to Ulker \&Gu (Kurniati,2016), Traditional plays are developmentally appropriate and they would be very advantageous when teaching academic subject. Roles and rules that are played in each game will reflect and guide them to understand the important things in their environment. As propounded Dockett \&Fleer (Kurniati, 2016) that within their play, children adopt roles and rules that have social and cultural base.

\section{METHODS}

This study, as a preliminary study, are trying to describe Rumah Pendidikan Asah Asih Asuh to develop local culture among children that join with this community. This study uses qualitative approach by conducting interviews with three Rumah Pendidikan Asah Asih Asuh initiators for data collection. And for secondary data, this study also use observation, group interview with parents, and also literature review.

- Interview with Mr. Guntur ( $1^{\text {st }}$ initiator $)$ on May 4, 2016 and May 16, 2016

- Interview with Ms. Effy ( $2^{\text {nd }}$ initator $)$ on April 23, 2016 and May 11, 2016

- Interview with Mr. Zulfi ( $3^{\text {rd }}$ initiator) on May 11, 2016 and May 16, 2016

- Observation from May 11, 2016 - June 15, 2016

- Group interview with parents on June 17, 2016

\section{RESULT AND DISCUSSION}

Based on interviews and observations found that the initiator makes this community non-profit. Operational funding is voluntary, some children free. Local cultural development activities carried out in the afternoon 5 times a week at $4 \mathrm{pm}$ to $6 \mathrm{pm}$. Related to the development of local culture conducted at Rumah Pendidikan Asah Asih Asuh are:

1. Activities undertaken in the form of a group game which allows the interaction between the players intensively.

2. The division is not based on age group, but all the children involved. This allows games were more complicated can not be followed by children younger. However, with their age levels allow for cultural transformation. younger children will be taught the older of the rules of the game and they will supervise and guard the younger ones in order not wrong.

3. At the time children play traditional games, a variety of indicators appear related to the development of social skills of children. such as taking turns to alternate roles, 
practice patience when it comes to perform the same role continuously losing, establish cohesiveness between one and the other.

4. Traditional games which conducted give a role to develop other aspects of development, such as motor skills, language, creativity, and emotion. interactions that arise when the game goes on unconsciously develop many aspects of development among other languages, where children will communicate both verbally and with gestures that they each understand its meaning.

Further observed also found that many traditional game using physical activity as the game that made them trained motor ability. Creativity comes when they have to determine a strategy to win. they will talk to each other emotionally that makes them more tolerant to accept another friend input and desires of others who proved the completion of the conflicts that arise during the game.

5. After the game, the facilitator will collect all to be given an explanation of the rules and the track of the game earlier. The facilitator will convey the relationship game with everyday life as related to cultural understanding and sensitivity tolerance in his explanation.

After more than a year they make this community, the results indicate that the initiators feels the children develop positively after join this community. They see that this community helps them gain tolerance to others.

Based on group interviews with parents found that they see that this community helps their children gain tolerance to others. The children also more polite and respect to their parents. But they feel the need to have the knowledge and skills regarding what they should do at home in order to balance the teaching conducted in the Rumah Pendidikan Asah Asih Asuh for optimal results. Parents also feel confused in educating at home related to the development of local culture.

Based on this research, we can know that the traditional game can be used as one method to develop local culture. However, it is understood some of highlights to be discussed further.In implementing traditional play, several things need to be considered:
1. Plurality age of children. The wider range of ages it is increasingly difficult to do the type of game that will do optimal function. this is because the developmental tasks each period a different age. it definitely affects the types of games are used. therefore expected in the future to focus more on the group game according to period developments or age range.

2. Various kind of games. This type of game adjusted by the learning objectives. therefore it would be better if the first arranged learning modules so that more planned so it is more effective in transferring knowledge. In addition to select games appropriate developmental age will help them grow more optimally match development period tasks. Group games still needed to play because they still need interact with others. Also, traditional games known as a high touch games that develop many social aspect.

3. Feedback that fasilitator gives to internalize local value. facilitator is an important factor related to the development of local culture. therefore the facilitators need to be equipped communication techniques so that the delivery that he did can be internalized to children. style that is attractive, examples are approaching their daily lives necessary for them to understand explanation of the facilitator.

\section{CONCLUSION}

In order to develop local culture in Rumah Pendidikan Asah Asih Asuh, playing traditional games are still needed and can not be replaced by high technology gadget-based games. Playing traditional games is one form of social interaction are used to develop social skills who became one of the peculiarities of local culture in Indonesia. Family support also important to support the program. by inviting the family as part of the development of the children will get a more comprehensive learning experience so that the results would be be optimized.

\section{ACKNOWLEDGEMENT}

In this study, researchers focused only on one community. In the future, it is possible to discuss a more diverse community that discovered methods 
which more effective in the development of local culture in Indonesia.

Related with Rumah Pendidikan Asah Asih Asuh, is expected Rumah Pendidikan Asah Asih Asuh make preparations more mature in the learning process conducted for the development of the local culture so that obtain maximum results in the future and also the development process more effective.

\section{REFERENCES}

Bordova, Elena\&Leong J. Deborah, 2003, Do Play and Foundation Skills Need to Compete for The Teacher's Attention in Early Childhood Classroom. Journal ERIC Digest

Florida Departement of Children and Families, 2013, Understanding Developmentally Appripriate Practices, Date of Acces: 15/08/2016.

http://www.collierschools.net/cms/lib/FL01903251/C entricity/Domain/1439/UDAP_Overheads.pdf

Kurniati, Euis,2006, Program Bimbingan Untuk Mengembangkan Keterampilan Sosial Anak Melalui Permainan Tradisional. Unpublished Thesis. Bandung : Universitas Pendidikan Indonesia

Kurniati, Euis, 2016, Permainan Tradisional \&Perannya dalam Mengembangkan Keterampilan Sosial Anak. Jakarta: Prenamedia Group

Mendikbud, 2015, Peraturan Menteri Pendidikan dan Kebudayaan Republik Indonesia No. 23 tahun 2015 tentang Penumbuhan Budi Pekerti. Date of Access: 10/03/16.
http://jdih.kemdikbud.go.id/asbodoku/media/peruu/Pe rmendikbud_Tahun2015_Nomer023.pdf

Mendiknas , 2003, Undang-Undang Republik Indonesia No. 20 tahun 2003 pasal 3 UU Sisdiknas tentang Sistem Pendidikan Nasional. Date of Access: 10/03/16.

http://sindikker.dikti.go.id/dok/UU/UU20-2003Sisdiknas.pdf

Musfiroh, Tadkiroatun, 2005, Bermain Sambil Belajatr dan Mengasah Kecerdasan. Jakarta: Depdiknas

National Association for the Education of Young Children, 2009, Developmentally Appropriate Practice in Early Childhood Programs Serving Children from Birth through Age 8: A position Statement of the National Association for the Education of Young Children. Dates of access: $10 / 05 / 2016$.

https://www.naeyc.org/files/naeyc/file/positions/posit ion\%20statement\%20Web.pdf

Syaodih, Ernawulan., Kurniati, Euis., Rachmawati, Yeni., Kurniawati, Leli., 2006. The Effectiveness of Traditional Plays In Developing Social Skill (An Experimental Study in B1 and B2 Class in UPI Laboratory Kindergarten 2006). Date of access: 18/08/2016.

http://file.upi.edu/Direktori/FIP/JUR._PGTK/197706 112001122-

EUIS_KURNIATI/THE_EFFECTIVENESS_OF_TR ADITIONAL_PLAY.pdf 